\title{
Ethnologies
}

Locked in the Family Cell: Gender, Sexuality and Political Agency in Irish National Discourse. By Kathryn A. Conrad. (Madison: University of Wisconsin Press, 2004. Pp. xiii +179 , illustrations, index, ISBN: 0-299-19650-X, cloth.)

\section{Robin Whitaker}

Volume 27, numéro 2, 2005

Terrains disputés

Contested Geographies

URI : https://id.erudit.org/iderudit/014055ar

DOI : https://doi.org/10.7202/014055ar

Aller au sommaire du numéro

Éditeur(s)

Association Canadienne d'Ethnologie et de Folklore

ISSN

1481-5974 (imprimé)

1708-0401 (numérique)

Découvrir la revue

Citer ce compte rendu

Whitaker, R. (2005). Compte rendu de [Locked in the Family Cell: Gender, Sexuality and Political Agency in Irish National Discourse. By Kathryn A. Conrad. (Madison: University of Wisconsin Press, 2004. Pp. xiii + 179, illustrations, index, ISBN: 0-299-19650-X, cloth.)]. Ethnologies, 27(2), 279-282.

https://doi.org/10.7202/014055ar d'utilisation que vous pouvez consulter en ligne. 
Locked in the Family Cell: Gender, Sexuality and Political Agency in Irish National Discourse. By Kathryn A. Conrad. (Madison: University of Wisconsin Press, 2004. Pp. xiii + 179, illustrations, index, ISBN: 0-29919650-X, cloth.)

Anyone familiar with recent Irish history will know how often disputes about nation, state and social order have been conducted on the ground of sexual politics. Abortion, declared unconstitutional in the Irish Republic in 1983, has featured prominently in debates about Ireland's relationship to Europe. The 1980s and 1990s saw a series of high-profile cases involving infanticide, the death of an adolescent in the Marian grotto where she went to give birth, and disputes about whether a suicidal fourteen-year-old rape victim should be allowed to travel to England for an abortion. In Northern Ireland, homosexuality was decriminalised considerably later than in the rest of the United Kingdom and only after resistance in the form of a "Save Ulster from Sodomy" campaign. The jurisdiction remains exempt from British abortion law, with politicians across the unionist-nationalist divide determined to keep it that way.

For Kathryn Conrad, these phenomena are inseparable from a conviction that national integrity rests on the heterosexual family and a clear public/private dichotomy. Locked in the Family Cell sets out to provide a focused examination of how this equation has played out on both sides of the Irish border. On the most immediate level then, the work speaks to questions of critical concern to feminists, gay activists and scholars of (Northern) Irish politics and culture. It also addresses theoretical questions about gender, sexuality and nation, public and private that, as Conrad notes, should be of wide interest beyond Irish studies.

The title of her introduction, "Informing on the Irish Family Cell," incorporates two of her key conceptual hooks. "Cell" suggests an analogy between prison, biological, and paramilitary cells and the family as fundamental social unit (the Republic's constitution enshrines it thus). In each case, emphasis is on self-regulation and enclosure. For order to prevail, anything destabilising must be neutralised by containment or expulsion. The consequences are most obvious for those who do not fit the model, but even the seemingly privileged are "trapped within the family cell" (4). 
"Informing" likewise carries multiple inflections: communicating knowledge, influencing, and divulging evidence against another. In a national or insurgent context, informers - those who disclose intelligence proper to the cell - are seen as traitors or spies, disloyal or alien elements who endanger the nation or nation-in-waiting. As Conrad argues in a later chapter, this helps explain why homosexuality has so often figured as foreign in Irish (and other) national discourses. But this negative sense of informing requires a clear division between public and private Conrad says, for otherwise "subjects can move freely in the public sphere, offering alternatives to a nationalist discourse based on a limited and limiting notion of the family cell" (16). Thus, Conrad argues, those who inform against the family cell, exposing its inner (dys)functions, offer the best hope for liberation and an invigorated public sphere.

She develops her case in three substantive chapters. Chapter one deals with representations of homosexuality in Irish political discourse, from the trial of Roger Casement through the history of gay rights activism and legislative reform in Britain, Northern Ireland and the Irish Republic. It winds up with the Irish Lesbian and Gay Organisation's exclusion from New York's St. Patrick's Day parade and a brief reflection on the relative openness of the Celtic Tiger climate. Chapter two examines abortion debates on both sides of the border, as well as a number of high-profile individual cases. Conrad ends with a chapter connecting her arguments about the family cell to Northern Ireland's conflicted political status. In particular, she suggests that the dominance of the "two communities" framework for Northern politics is both based on and perpetuates a family cell model in which agents of the state and those resisting it have been heavily invested in controlling information between public and private spheres. In each chapter, Conrad supplements her account of empirical events with analyses of relevant fiction, poetry and films.

Conrad is strongest in her suggestive analysis of how the gendered discourses of nationalism, nation/state sovereignty and the public/private dichotomy have worked to constitute the political landscape — and limit political agency — even for those who refuse the privileged confines of the heterosexual family cell. Thus, for example, decriminalising homosexuality in both Northern Ireland and the Republic ultimately 
required quitting the national scene to appeal to the European Court of Human Rights. Both cases were won on privacy rights, which, as Conrad observes, had contradictory implications. Even as they challenged the conflation of privacy with the heterosexual family, they privatised - and to that extent, depoliticised - the scene of gay freedom. Interestingly, when the Republic finally decriminalised male homosexual activity in 1993, advocates described it as an embodiment of "traditional Irish values arising from the anticolonial struggle," (23) "wiping the lingering shame of British imperial statute from the record of Irish law" (53). Pro-choice activists have not yet had the chance to use this line.

Conrad's reliance on secondary sources, even for material that is easily accessible in the original (the Northern Ireland Assembly Hansard, for example), may help explain a number of minor errors. These don't undermine her thesis, but they suggest her main interest lies in the logic of political discourse not the nitty gritty of political consciousness and action, which is often contradictory. In the context of the Republic, I was surprised that she neglected such key sources as Tom Inglis' Moral Monopoly, as well as events and debates relating to contraception, the divorce referenda of 1986 and 1995, the impact of sex abuse scandals in the Catholic Church, secularisation, the vast increase in women's employment, and the 1990 election of Mary Robinson, an outspoken feminist, as president. In her chapter on Northern Ireland, I wanted a more careful analysis of just who or what was entailed in repeated references to "women and queers" - especially women. Queer, at least, carries a discernible political connotation. But alongside those women actively troubling the public/private and sectarian divisions are myriad others who form the vaunted "backbone" of conservative religious activism.

Conrad's book ends with Chapter three. Perhaps it is appropriate that there is no separate conclusion. Many of the questions Conrad is treating remain unresolved. But what is to be done? Precisely because I agree that the politics of nationality and the existing opposition of public and private constrain political life, I wanted a clearer idea of her alternatives. In this regard, I couldn't help wondering why she didn't confront, head-on, the one institution that arguably underpins the whole family cell/state-nation complex: that of state-sanctioned marriage. 
Conrad set out to inform against the family cell. This book is a good start, but there's more to tell yet.

\author{
Robin Whitaker \\ Memorial University \\ St. John's, Newfoundland
}

\title{
Reference
}

Inglis, Tom. 1987. Moral Monopoly: The Catholic Church in Modern Irish Society. Dublin: Gill and Macmillan.

Tortillas and Tomatoes. Transmigrant Mexican Harvesters in Canada. By Tanya Basok. (Montréal and Kingston, McGill-Queen's University Press, 2002. Pp. 168, ISBN 0773523871)

Basok's Tortillas and Tomatoes brings to light rich reflections on the problems facing Canadian agriculture, mostly in terms of committed labour shortages during specific time periods of the year. Tomatoes and Tortillas gets points for originality for dealing with Canada and Mexico, two countries that are rarely brought together despite the fact that exchanges of people, capital, and goods continue to expand. These two national realities are presented separately in the book, with the first part dealing more with the problems facing Canadian fresh produce agriculture and greenhouse production, while the second part analyses the migration of Mexican workers, their living conditions in Canada (Leamingford County, Ontario), and Mexican rural poverty. By the end of the book, any loose ends are tied as the author sheds light on the interdependence that has been cultivated between Canadian growers and offshore Caribbean and Mexican labour within the context of the government-led farm workers' program. Although this interdependence is not explicit in the text, the reader is led to understand how offshore labour programs offer mutual benefits (employment and income in exchange for committed labour in the fields), which allow both migrants and growers to gain while continuing to pursue their own individual interests.

Basok's deep understanding of the conditions met by migrant workers in Canadian fields has been carefully supplemented with an equally deep knowledge of the history of rural development in Mexico and the 